\section{HORSE-BREEDING AND HORSE-RACING.}

THE history of the English racehorse is a chequered one. During the Wars of the Roses many studs were dispersed, but owing to the re-importation of horses from the Continent during the reign of Henry VIII. the thoroughbred breed was re-established. Later, owing to the importation of numerous Oriental and other alien stallions and mares, the English breed of racehorses was for years in the melting-pot. In I649 the Royal Tutbury Stud was handed over to Parliament, but a few years later Cromwell, though himself an owner of racehorses, found it necessary "for political reasons" to stop racing. History has been repeating itself. A valuable stud has recently been handed over to the Government, and racing has once again been virtualiy suspended. Further, some people not unduly biased by the objectionable features of race-meetings are asking, "Is racing necessary to maintain the pre-eminence of the English racehorse?" while others, including Sir H. H. Johnston, want to know "whether the type of horse that is evolved from horse-racing is of any use nowadays?"

It is well to bear in mind that the racehorse industry is a large and important one, and that the large sums received for horses exported help to pay for the raw material required for bur cotton and other factories. But there is a more cogent reason than the economic one for preserving the racehorse. Unless we intend to retire once more to the fool's paradise we found so comfortable up to August, r914, it is essential that we not only preserve the thoroughbred, but also, by more scientific breeding, add greatly to its value for military and other purposes. Light as well as heavy horses have played an important part in the present war, and, notwithstanding mechanical traction, they may play a still more important part in future wars. Horses for military purposes should have the vigour, staying power, and tenacity of mules combined with the cross-country instincts of hunters. Such horses can be obtained only by cross-breeding. It would be difficult to create and maintain a breed of hunters, and still more difficult to create breeds of the old pack-horse type suitable for military purposes. This being the case, it will continue to be impossible to provide Army horses without the help of the thoroughbred. The modern English racehorse is said to be "more remarkable for speed than stamina "; nevertheless, crosses having a large infusion of thoroughbred blood have often as much staying power, intelligence, and courage as Arabs.

Hitherto, while Continental Powers have been spending annually large sums in beeding, or providing facilities for breeding, military horses, our Army Remount Department has looked to thoroughbred and other breeders to provide them with all the different types of service horses required, has, in fact. trusted to meet the demands of the Army by misfits obtained at a price which scaicely paid for their upbringing.

Many who realise the national importance of maintaining the English and Irish racehorses have some difficulty in realising that racehorse breeding implies racing. They admit that it is impossible to create and maintain herds of "xooo-gallon cows" without keeping milk records, and that unless records are kept it is impossible to have strains of "200-egg hens," but they fail to appreciate the importance of having continuous records giving the performance of racehorses. It is impossible by looking at or handling a cow to say whether or not her offspring will prove as good milkers as her pedigree suggests, for everything depends on the contents of the germ-cells, and the only way to obtain information about the composition of the germ-cells is to test the milking powers of the offspring. When a thoroughbred stallion has a distinguished racing record there is a probability that he will preve a successful sire, but the only sure test is the performance of his offspring. As thoroughbreds are an unstable blend of several distinct types they rarely breed true, hence breeders in selecting stallions should be guided mainly by the racing records of their offspring. Sometimes indifferent performers acquire great distinction at the stud. "Stockwell" is said to have achieved at the stud "the most brilliant success of any sire of all time," and he is often referred to as the Emperor of Stallions. The sire of "Stockwell" ("The Baron") was the son of the very unattractive, fiddle-headed mare "Echidna," who was never saddled; "Stockweil's" dam ("Pocahontas") was a bad roarer and an indifferent performer on the Turf and deficient in quality, yet "Pocahontas," through "Stockwell," "Rataplan," "King Tom," and others who inherited her immense vitaiity, did much to increase the stamina of the modern English racehorse. But for the racing test the value of the "Pocahontas" and "Echidna" blood would never have been realised.

The necessity of testing the speed, endurance, etc., of possible sires was first realised about the beginning of the seventeenth century, but the importance of directing more attention to the performance of the offspring than to that of either sire or dam is not yet sufficiently recognised. During a considerable part of last century the practice of considering almost exclusively the records of the sire did little harm, because (as Osborne points out in his "Horse-breeders" Handbook") in former times one out of every three horses bred could win a race, but since the 'eighties it is doubtful if more than one in twenty of the horses bred has won a race. That a change has taken place since it became the fashion to have large sales of yearlings is supported by Sir Walter Gilbey, who, in 1898 , pointed out that twenty-two yearlings, sold in 1895 for 46,200 guineas, only won three races in 1897 worth ro8ol., and that twenty-two, sold for 34,850 guineas as yearlings in 1894 , had failed, when their racing career was nearly over, to earn one-half of what they originally cost. Obviously, if only about 5 per cent. of the racehorses bred have the speed and endurance required to win a race, it is important that facilities should be provided for systematically testing young horses as soon as their training is sufficiently advanced. Breeding racehorses with- 
out applying racing tests is bound to lead to deterioration. For this reason the continuance of such racing as may be required to test the value of the stallions and mares now at stud is essential.

J. C. Ewart.

\section{THE DESTRUCTION OF HOUSE- SPARROWS.}

THE question whether or not a particular species of wild bird is injurious or beneficial is one that is difficult to answer, but it is manifestly unfair to complicate the matter further by raising issues that are foreign to the subject, or by the publication of random statements which are not substantiated by actual facts.

Recently in the Times a correspondent recorded "a plague of caterpillars such as are taken by the sparrows to feed their young," and deplores the action of the Board of Agriculture in issuing an Order for the destruction of the house-sparrow. Unfortunately, the correspondent does not mention the species to which this caterpillar belongs; presumably it is the larva of the Winter Moth (Cheimatobia brumata, L.), upon which the housesparrow feeds its young during the nestling period, but only to a limited extent. For years past we have had plagues of caterpillars when house-sparrows were free to breed and multiply, and careful inquiry has shown that such outbreaks are almost universally due to the omission of grease-banding of the fruit trees, or, in the case of other species, to the absence of the spraying machine. Owing to the present scarcity of labour, either of these reasons may account for the plague of caterpillars, so that the demand for "the immediate reversal of the orders given" by the Board of Agriculture is unjustifiable. In view of the above and similar statements now appearing in the Press, it may be well once more to state the economic position of the house-sparrow as related to agriculture and horticulture.

First, the writer would like to state that he is in full agreement with the action of the Board of Agriculture, believing from long experience and close study of the food and feeding habits of the house-sparrow that, as a result of its recommendation, great benefit will accrue to both the agriculturist and the horticulturist.

Gurney, who investigated the food of this species in 1885 , stated that "fully 75 per cent. of an adult sparrow's food during its life is corn of some kind. In young sparrows not more than 40 per cent. is corn, while about 40 per cent. consists of caterpillars and ro per cent. of small beetles. This is up to the age of sixteen days." This statement was founded upon an examination of 694 dissections. In roro the writer commenced to work upon this species, and by June, r9r4, had examined 404 adults and 329 nestlings, obtained from fruit-growing, agricultural, and suburban districts. Since then the work has been continued, so that up to the present time upwards of $75^{\circ}$ adults and 470 nestlings have been investigated, and the results clearly show :-

(i) That the house-sparrow is far too plentiful, No. 2487, VOL. 99] and in agricultural and suburban districts it still requires very drastic reduction.

(ii) That, to a less extent, perhaps, it requires reducing in number in fruit-growing districts, and were this carefully carried out annually, after the nesting period, the good done during that season might probably compensate for the harm occasioned during the remainder of the year.

(iii) That in agricultural districts the food of 75 per cent. of the sparrows consists of corn.

(iv) That, apart from the nesting season, the house-sparrow does far more harm than good; indeed, its depredations on cereal crops alone entail a most serious loss to the farmer and the country in general.

As a result of the numbers of house-sparrows that are now, very wisely, being destroyed, we shall, in all probability, see a marked increase in the number of truly insectivorous birds, which are invaluable to the fruit-grower.

As to the continuance of the present Order, all must depend upon the number of birds destroyed in fruit-growing districts; but there is little fear, in the writer's opinion, of their extermination in agricultural or suburban districts, and there the Order might be wisely continued.

From the above recorded observations and those previously published, no unprejudiced mind will doubt the wisdom of a drastic reduction of this species. Enthusiasts and humanitarians may continue to write upon the value of this bird to the farmer, etc.; but the futility of such statements must be apparent to the most casual observer, unless they are supported by trustworthy and carefully obtained facts as to the precise nature and quantity of the food, while such investigations as have been conducted entirely fail to support the popular view that the insects destroyed during the nesting season compensate for the wide destruction occasioned by the species generally during the remainder of the year.

There is a very general, but entirely mistaken, opinion that the house-sparrow feeds largely upon insects. During the nesting season the food fed to the young birds, and in all probability most of that taken by the parents, consists mainly of insects, worms, and slugs; but during the remainder of the year it is mainly grain of some kind.

No thinking individual wishes or advocates the destruction of truly beneficial species of wild birds; on the contrary, every encouragement should be offered them, provided that they are not permitted to increase to such an extent that a change in their feeding habits is forced upon them by reason of their numbers.

Whilst the majority of species of wild birds are undoubtedly beneficial, no increase in their numbers will ever lead to the extermination of any of our common orchard pests. That they aid in the control of such pests is perfectly true, but so long as artificial conditions prevail-i.e. the association in a given area of a large number of trees of a particular species-so long will it be necessary to spray, grease-band, and carry out clean cultivation. If the house-sparrow is the 